\title{
Wpływ sytuacji komunikacyjnej na zachowania Jana Pawła II podczas spotkania z młodzieżą na Wzgórzu Lecha w 1979 roku
} The influence of the communication context on John Paul II's behaviour during a meeting with young people on Lech's Hill in 1979

\author{
Magdalena Jankosz \\ Wydział Nauk Społecznych, Uniwersytet Papieski Jana Pawła II w Krakowie, \\ ul. Kanonicza 25, 31-002 Kraków, Polska; \\ jankoszmagdalena@gmail.com
}

\begin{abstract}
Abstrakt
Celem mojego artykułu będzie pokazanie zachowań komunikacyjnych Jana Pawła II w określonej sytuacji komunikacyjnej. Problem badawczy zawiera się w pytaniu, jak sytuacja komunikacyjna determinuje zachowania mówcy. Materiałem źródłowym będzie nagranie wideo spotkania papieża z młodzieżą na Wzgórzu Lecha w Gnieźnie 3 czerwca 1979 r. oraz zapis jego przemówienia. Wybieram to wystąpienie jako najbardziej reprezentatywne dla omawianego zagadnienia. W pierwszej części omówię pojęcie sytuacji komunikacyjnej i jej typy, w drugiej wskażę czynniki wyróżniające spotkanie na Wzgórzu Lecha jako potoczno-okazjonalną sytuację komunikacyjną, w trzeciej zaś przeanalizuję werbalne i niewerbalne środki wyrazu wykorzystane w tym przemówieniu. Posłużę się w tym celu zintegrowaną metodę analizy komunikacyjnej.
\end{abstract}

Słowa kluczowe: sytuacja komunikacyjna; Jan Paweł II; gesty narracyjne; komunikacja werbalna.

\begin{abstract}
The aim of the article is to show the communication behaviour of John Paul II in a specified communication context. The article is an attempt at presenting how a communication context affects a speaker's behaviour. The analysis is based on a video recording of the pope's meeting with young people on Lech's Hill in Gniezno on 3 June 1979 and a recording of his speech. The reason why I have chosen this public address is the fact that it is the most representative for the discussed issue. The three parts of the article cover the concept of the communication context and its types (first part), the distinguishing factors of the Lech's Hill meeting as a common, occasional communication context (second part), an analysis of the verbal and non-verbal means of expression used in that speech (third part). For that purpose I use the integrated method of communication analysis.
\end{abstract}

Keywords: communication context; John Paul II; narrative gestures; verbal communication. 


\section{Pojęcie sytuacji komunikacyjnej}

Funkcjonuje wiele definicji i teorii dotyczących pojęcia sytuacji komunikacyjnej. Jedne kładą nacisk na jej pozajęzykowy charakter, inne zaś charakteryzują ją jako wydarzenie językowe (Sawicka 2010). Przydatne dla potrzeb niniejszego wystąpienia wydaje się ujęcie Elżbiety Laskowskiej, która sytuację komunikacyjną traktuje jako „zespół elementów towarzyszących wypowiedziom” (2010: 72). Do elementów tych autorka zalicza: typ nadawcy, typ odbiorcy, typ kontaktu, tworzywo oraz okoliczności fizyczne (Laskowska 2010). Wszystkie one mają wpływ na sposób ukształtowania wypowiedzi.

Istnieje kilka typologii sytuacji komunikacyjnych, uwzględniających różne kryteria. Przywołam tu typologię Stanisława Grabiasa ze względu na jej praktyczny charakter. Biorąc pod uwagę kryterium przewidywalności zachowań, wyróżnił on trzy typy sytuacji komunikacyjnej: rytualną, potoczną i okazjonalną (Grabias 1994). Sytuacje rytualne cechuje pełna przewidywalność zachowań, których reguły są ustalane instytucjonalnie. Sytuacjom potocznym z kolei właściwa jest względnie duża przewidywalność zachowań, ale ich reguły ustaliły się same, w trakcie wielokrotnie powtarzających się interakcji, nie są określone żadną instrukcją. Trzeci typ sytuacji, okazjonalny, odznacza się bardzo małą przewidywalnością zachowań; ich uczestnicy muszą sami ustalić elementy konstytutywne i sterować swoimi reakcjami.

Wydaje się, że powyższy podział nie jest wystarczający dla potrzeb materiału, który zamierzam analizować. $Z$ tego względu sytuacje rytualne proponuję podzielić na sakralne i świeckie. Te pierwsze wyróżnia kontekst liturgiczny, na ogół jest nim msza święta, te drugie natomiast determinuje kodeks dyplomatyczny. Ponadto uważam za konieczne dodanie jeszcze jednego typu sytuacji komunikacyjnej, mieszanego, potoczno-okazjonalnego, który łączy w sobie cechy obu tych sytuacji (Jankosz 2018).

\section{Spotkanie z młodzieżą na Wzgórzu Lecha jako przykład sytuacji potoczno-okazjonalnej}

Sytuacja komunikacyjna, w jakiej odbywało się spotkanie Jana Pawła II z młodzieżą na Wzgórzu Lecha podczas I pielgrzymki do Polski, to sytuacja potoczno-okazjonalna, ponieważ odnajdujemy w niej nie tylko utarte schematy zachowań, ale również te wykraczające poza przyjętą konwencję. Charakteryzuje się ona jednocześnie przewidywalnością i nieprzewidywalnością zachowań, widoczną w każdym elemencie tworzącym tę sytuację, czyli w typie nadawcy, odbiorcy, kontaktu, tworzywa oraz okolicznościach fizycznych.

Posługując się typologią E. Laskowskiej (2010), uznamy, że Jan Paweł II w tym wystąpieniu był nadawcą wyrazistym (dało się go ustalić w sposób niebudzący wątpliwości), znanym (wiadomo, kim był) i dostępnym (można było z nim nawiązywać kontakt). Nie można go jednak nazwać nadawcą stałym, typowym 
dla monologu, ponieważ w drugiej części wystąpienia nawiązał on dialog z wiernymi, przede wszystkim z młodzieżą, również ze zgromadzonym duchowieństwem. Nadawca stał się zatem zmienny - obok papieża był nim także prymas Stefan Wyszyński, który wszedł w konwencję dialogu i żartu zaproponowaną przez Jana Pawła II, oraz poszczególni reprezentanci młodzieży i całego zgromadzenia. Tym samym nie mamy tu też do czynienia z nadawcą indywidualnym, ale zbiorowym, choć oczywiście dominującą rolę odgrywał Jan Paweł II. Ta zbiorowość i zmienność nadawcy jest pierwszym czynnikiem, który możemy uznać za wyróżniający omawianą sytuację komunikacyjną.

Odbiorcą tego wystąpienia była przede wszystkim młodzież, ale także dzieci, osoby dorosłe i starsze, świeccy i duchowni - wszyscy zgromadzeni na Wzgórzu Lecha. Odbiorca jest tu więc również zbiorowy (w przeciwieństwie do odbiorcy pojedynczego), a także rzeczywisty (czyli znany nadawcy; Jan Paweł II wiedział, do kogo kieruje swoje słowa), aktywny (papież mógł obserwować reakcje werbalne i niewerbalne swoich słuchaczy), zamierzony (przekaz był skierowany właśnie do tej grupy wiernych, która zebrała się na Wzgórzu Lecha) i bezpośredni. Pojawił się tu również odbiorca pośredni, którym stali się telewidzowie. Warto zwrócić uwagę, że to właśnie typ odbiorcy okazał się w tym wypadku jednym z najważniejszych elementów sytuacji komunikacyjnej - przemawiając do ludzi młodych, papież sięgał po takie środki wyrazu, które pozwalały mu zbudować z nimi szczególną więź, a jednocześnie ujawniały jego sympatię, można powiedzieć słabość do młodzieży. Nie będzie chyba nadużyciem stwierdzenie, że była to uprzywilejowana grupa jego odbiorców, która determinowała typ sytuacji komunikacyjnej jako potoczno-okazjonalną.

Jeśli chodzi o typ kontaktu między nadawcą a odbiorcą, mamy tu do czynienia z nierównorzędnością społeczną ról i ich instytucjonalnym charakterem - Jan Paweł II przemawiał jako papież, głowa Kościoła katolickiego. Widoczna jest także naturalna w związku z tym przewaga nadawcy. Trudno określić stopień trwałości tego kontaktu, ponieważ wśród odbiorców znajdowały się osoby z najbliższego grona Jana Pawła II, dominowali jednak ludzie, dla których był to kontakt jednorazowy. Trzeba też zaznaczyć, że w wymiarze duchowym ten jednorazowy kontakt przeradzał się niejednokrotnie w permanentny. Elementem, który w zakresie typu kontaktu wyróżnia tę konkretną sytuacją komunikacyjną, był natomiast jego mieszany, oficjalny i jednocześnie nieoficjalny charakter. Na ogół nierównorzędność społeczna ról i ich instytucjonalny charakter pociąga za sobą bardzo oficjalny charakter wystąpienia. W tym wypadku było inaczej: początkowo ta oficjalność była dominująca, jednak z czasem stawała się coraz mniej istotna, kontakt między Janem Pawłem II a zgromadzonymi zaczął nabierać cech niemalże towarzyskich, przyjacielskich ${ }^{1}$.

1 Janusz Poniewierski (2006: 40) zauważa: „Dziś to wydaje się nam oczywiste, ale wystarczy obejrzeć stare filmy, na przykład z pierwszej pielgrzymki do Polski, na których Jan Paweł II przekomarza się z młodzieżą, a prymas Wyszyński jest lekko zgorszony, że można tak bezceremonialnie rozmawiać z papieżem!"”. 
Uwzględniając kryterium tworzywa, spotykamy się tu z sytuacją mówioną, wykorzystującą kanał słuchowy. Niezwykle ważny był ponadto kanał wzrokowy niewerbalne zachowania Jana Pawła II pełniły bardzo istotną funkcję komunikacyjną. Mamy tu do czynienia $\mathrm{z}$ wymieszaniem tworzywa. Papież nie tylko przemawia, ale również śmieje się, śpiewa, skanduje, ponadto żywo gestykuluje. Wychyla się przez barierkę balkonu, na którym stoi, próbując zmniejszyć dystans między sobą a swoimi słuchaczami. Ten właśnie element: wymieszanie tworzywa, a także uaktywnienie zarówno kanału słuchowego, jak i wzrokowego nadawcy, można uznać za wyróżniający sytuację potoczno-okazjonalną.

Ostatnim czynnikiem omawianej sytuacji komunikacyjnej są okoliczności fizyczne, czyli czas i miejsce kontaktu. Czas był wspólny dla nadawcy i odbiorcy (tzw. spójny czas akcji), miejsce kontaktu zaś otwarte, plenerowe. Takie właśnie miejsce umożliwiało papieżowi pewne niekonwencjonalne zachowania. Oczywiste wydaje się, że w katedrze, przy ołtarzu, jego postawa byłaby inna, nie ujmowałby się pod boki, pewne żarty nie zostałyby wypowiedziane, tam by nie skandował, nie śpiewał harcerskich piosenek. Plener pozwala na pewną swobodę zachowań. I takie właśnie otwarte miejsce kontaktu uznaję za kolejny czynnik wyróżniający omawianą sytuację komunikacyjną (z zastrzeżeniem, że nie jest ono zarezerwowane tylko dla niej, ale w jej obrębie jedynym możliwym).

\section{Sytuacja potoczno-okazjonalna a zachowania komunikacyjne Jana Pawła II}

W sytuacji potoczno-okazjonalnej, w jakiej odbywało się spotkanie papieża z młodzieżą na Wzgórzu Lecha, obserwujemy werbalne i niewerbalne zachowania Jana Pawła II.

\subsection{Zachowania werbalne}

Do tej grupy możemy zaliczyć m.in. posługiwanie się figurami retorycznymi, a także dialog, humor, śpiew.

Figury retoryczne to „szczególne sposoby kształtowania wypowiedzi wyróżnione i sklasyfikowane przez antyczną retorykę, gramatykę i poetykę jako właściwe sztuce oratorskiej i poetyckiej, a więc niedostępne zwykłemu, pospolitemu porozumiewaniu się" (Głowiński i in. 1976: 120). W wystąpieniu Jana Pawła II pojawiają się takie figury retoryczne (Korolko 1990), jak np.:

- anafory - polegające na powtarzaniu tego samego zwrotu lub słowa na początku zdań czy okresów w celu semantycznego uwydatnienia myśli, np.: „Kultura jest przede wszystkim dobrem wspólnym narodu. Kultura polska jest dobrem, 
na którym opiera się życie duchowe Polaków. Ona wyodrębnia nas jako naród. Ona stanowi przez nas przez cały ciąg dziejów"2.

- epifory - polegające na powtarzaniu tych samych słów lub zwrotów na końcu zdania lub okresu, np. „Przyjdź i umocnij w nich tę miłość, z której się kiedyś poczęła pierwsza polska pieśń Bogurodzica: orędzie wiary i godności człowieka na naszej ziemi. Polskiej, słowiańskiej ziemi”.

- anadiplozy - polegające na rozpoczynaniu zdania lub członu zdania wyrazem znajdującym się na końcu poprzedniego zdania lub członu, np. „Czym jest kultura? Kultura jest wyrazem człowieka”. Znaczna liczba tego typu figur potwierdza tezę Jana Miodka, że powtórzenia były ulubionym środkiem retorycznym papieża (Miodek 1998).

- apostrofy - bezpośrednie zwroty do odbiorcy (np. „Moi kochani”, „Moi drodzy” - do młodzieży, „Światłości młodych polskich sumień - przyjdź. Przyjdź Duchu Święty" - do Ducha Świętego).

- pytania retoryczne - zadane nie w celu uzyskania odpowiedzi, ale nakłonienia odbiorcy do zastanowienia się nad jakimś problemem (np. „Czym jest kultura? Kultura jest...").

- eksklamacje - figury konstruowane zwykle w formie zdania wykrzyknikowego, służące do wyrażania nagłego wzruszenia, gwałtownych emocji, wezwania, ważnego apelu („Pozostańcie wierni temu dziedzictwu!”, „Marsz do Poznania").

Środki retoryczne wykorzystywane przez Jana Pawła II nie przesłaniały nadrzędnego celu wypowiedzi i były stosowane w bardzo etyczny sposób. Nigdy nie służyły do manipulacji odbiorcą. Jak zauważa Agnieszka Kulik-Jęsik, papież, będąc doskonałym mówcą, ,skutecznie neguje rzymskie powiedzenie retorów: «Słowo uczy, słowo niszczy». Nadaje mowie rolę oczyszczającą, nawracającą, nakierowaną na propagowanie idei dobra" (Kulik-Jęsik 2009: 135). Wykorzystywał on rozmaite tropy stylistyczne w sposób wyważony, a nie ostentacyjny. Nie używał chwytów erystycznych, które odwoływały się do niewiedzy audytorium, litości, próżności słuchaczy itp., ponieważ uważał je za nieetyczne. „Stosował figury argumentacji racjonalnej, aby krok po kroku wnioskować, uzasadniać przesłanki, pokazywać alternatywy, analogie, a tym samym w sposób wiarygodny, udokumentowany nieść światu orędzie miłości, wiary i nadziei na lepsze jutro" (Kulik-Jęsik 2009: 145).

Innym zachowaniem werbalnym Jana Pawła II w analizowanym wystąpieniu był humor rozumiany jako pewna dyspozycja twórcza „do ujmowania zjawisk życia [...] w kategoriach komizmu" (Głowiński i in. 1976: 158), do ukazywania ich w sposób pobudzający do śmiechu. Humor może być związany z płaszczyzną językową, sytuacyjną, postaci. Jan Paweł II podczas spotkania z młodzieżą

2 Wszystkie cytaty z przemówienia podaję za tekstem opublikowanym w zbiorze Jan Paweł II, Pielgrzymki do Ojczyzny. Przemówienia, homilie (2012). 
wykorzystywał zarówno humor sytuacyjny (np. kiedy podczas okrzyków „Niech żyje papież” śmiał się i wołał: „Ho, ho, ho”), jak i humor słowny (np. kiedy mówił: „Tak się pocieszam. «Już trzy dni trwają przy mnie». Powiedział w Ewangelii Pan Jezus. Ale zaraz mi przychodzi na myśl już nie z Ewangelii, ale tak po prostu z chłopskiego rozumu ludzkiego takie inne zdanie, które mówi: «Ty nie rób się Panem Jezusem»").

Kolejnym zachowaniem werbalnym wykorzystanym podczas spotkania z młodzieżą był dialog, czyli rozmowa. „Dla dialogu charakterystyczna jest wymienność ról nadawcy i odbiorcy wśród jego uczestników: ta sama osoba występuje raz jako podmiot mówiący, to znów jako adresat słów wypowiadanych przez innego rozmówcę" (Głowiński i in. 1976: 73). Dialog nie pojawia się na ogół w oficjalnych wystąpieniach, stosuje się go natomiast powszechnie w mowie potocznej. Nie tylko pozwala on na wymianę myśli, poglądów czy argumentów, ale pomaga także stworzyć międzyosobową więź. Taka więź między Janem Pawłem II a młodzieżą powstawała bardzo szybko. Podczas omawianego spotkania papież prosił np. o przypomnienie mu słów danej pieśni, a młodzież w odpowiedzi śpiewała. Kiedy młodzi krzyczeli „Niech żyje papież”, odpowiadał np. „Dość już tego dobrego" albo „Marsz do Poznania”.

Jako szczególny rodzaj zachowania werbalnego w analizowanym przemówieniu pojawia się śpiew. Jan Paweł II, dysponujący donośnym, mocnym głosem i dobrym słuchem, śpiewał podczas tego spotkania zarówno piosenki turystyczne, harcerskie czy ludowe, np. Góralu, czy Ci nie żal; Ptonie ognisko w lesie; Sto lat; Idzie noc, jak i pieśni religijne - I chodź ze mna zbawiać świat; Apel jasnogórski, a także hymn państwowy - Mazurek Dąbrowskiego.

W powyższym zestawieniu zwraca uwagę duża różnorodność zachowań werbalnych. Wynika ona z tego, że wystąpienie miało dwie części. Pierwsza z nich była typową mową retoryczną o charakterze uzasadniającym, druga natomiast improwizowaną rozmową. W tej pierwszej części papież wykorzystywał figury retoryczne typowe dla wystąpień publicznych, w drugiej części zachowywał się natomiast spontanicznie, nieprzewidywalnie.

\subsection{Zachowania niewerbalne}

Analizę niewerbalnych zachowań komunikacyjnych Jana Pawła II ograniczę do opisu jego gestów narracyjnych. Mogą być one odczytywane wyłącznie w kontekście towarzyszącego im tekstu i bezpośrednio wpływają na tok narracji. Gesty te nie tylko wzmacniają przekaz werbalny, ale są równorzędnym - w stosunku do słowa - środkiem komunikacji i uczestniczą w kreowaniu znaczenia wypowiedzi. Do gestów narracyjnych zaliczam - za Jolantą Antas - batuty, ilustratory i gestualne metafory (2001).

Spośród gestów narracyjnych, jakie wykonywał Jan Paweł II podczas omawianego wystąpienia, zdecydowanie dominowały gesty batutowe. Batuty to szybkie, rytmiczne i zsynchronizowane z prozodycznymi właściwościami mowy ruchy 
rąk, określane także mianem uderzeń. Batuty wiążą się z akcentami i rytmem wypowiedzi, ponadto pomagają logicznie posegmentować tekst, ale przede wszystkim pełnią funkcję semantyczną - pokazują, które fragmenty tekstu są dla odbiorcy najważniejsze i jaki jest jego stosunek emocjonalny do wypowiadanych treści (Załazińska 2016). Batuty możemy podzielić na dwie grupy: są to rytmiczne uderzenia ręką w powietrzu, wykonywane na ogół w przestrzeni przed sobą (ostre i cięte lub bijące), a także delikatniejsze chwyty w powietrzu, mające charakter precyzowania, dookreślania (Antas 2001). Batutę należącą do tej pierwszej grupy Jana Paweł II wykonał m.in., wypowiadając słowa: „Wiadomo, że naród polski przeszedł przez ciężką próbę utraty niepodległości, która trwała z górą sto lat - a mimo to pośród tej próby pozostał sobą. Pozostał duchowo niepodległy, ponieważ miał swoją kulturę". Prawą rękę, w której nie trzymał tekstu przemówienia, Jan Paweł II zacisnął i kilka razy wyraźnie podniósł ją w górę i w dół, potrząsając nią. Zaciśnięcie pięści towarzyszyło słowom: „ciężka próba” oraz „pośród tej próby pozostał sobą”. Widać zatem wyraźnie, że to słowa próba zasługuje na szczególną uwagę i ono zostaje przez papieża bardzo wyraźnie zaakcentowane. Tak zwana batuta pięści wyraża na ogół moc i władzę mówiącego (Antas 2001). Jan Paweł II podkreśla gestem także wagę wypowiadanych słów. Powtarza tę batutę raz jeszcze, już po zakończeniu wypowiedzi, jakby ponownie chciał zaakcentować, już samym tylko gestem, fakt, że kultura uratowała naród. Batuta pięści wzmacnia perswazyjność wypowiedzi, dlatego papież wykorzystuje ją we wskazanym miejscu - zależy mu, aby przekonać odbiorcę do wagi swoich słów. Ujawnia tym samym swój stosunek emocjonalny do przekazywanej treści.

Inną batutą wykorzystywaną przez Jana Pawła II jest batuta palca wskazującego. Mówiąc o tym, że „Ona [kultura] wyodrębnia nas jako naród. Ona stanowi o nas przez cały ciąg dziejów. Stanowi bardziej niż siła materialna. Bardziej nawet niż granice polityczne", papież unosi palec wskazujący do góry, następnie go opuszcza i powtarza ten gest kilka razy. Moment podniesienia palca nakłada się dwa razy ze słowem „bardziej”, tak jakby batuta ta podkreślała również stopniowanie zawarte $\mathrm{w}$ warstwie werbalnej. Palec skierowany w górę ma za zadanie wskazywać treści ważne (Antas 2001). Papież podkreśla tym gestem znaczenie kultury dla narodu. Batuta palca wskazującego wiąże się tu z perswazyjnym charakterem wypowiedzi, odsyła do postawy nauczyciela, który przekazuje ważne informacje (Antas 2001).

Nieco zmodyfikowana batuta palca wskazującego towarzyszy słowom: „Pozostańcie wierni temu dziedzictwu. Uczyńcie je podstawą swojego wychowania! Uczyńcie je przedmiotem szlachetnej dumy! Przechowajcie to dziedzictwo! Pomnóżcie to dziedzictwo! Przekażcie je następnym pokoleniom!". Palec wskazujący papieża skierowany jest bezpośrednio w stronę odbiorców, nie w górę. To do nich adresowany jest apel, oni mają go wypełnić. Batuta taka (tzw. cios werbalny) ma charakter nakazowy, podkreśla tryb rozkazujący, który jest użyty w zdaniu. Wzmacnia także wykrzyknienia, którymi posługuje się tu mówca. Znamienne jest, że papież wyciąga palec $\mathrm{w}$ stronę audytorium dokładnie przy słowach: 
„przechowajcie” i „pomnóżcie”, czyli przy konkretnych apelach, wezwaniach, pokazując, że są one najważniejsze.

Wymienione gesty pozostają $\mathrm{w}$ ścisłej relacji z figurami retorycznymi wykorzystywanymi przez papieża, omówionymi wcześniej. Batuty dominują w tych fragmentach, gdzie pojawiają się anafory, epifory, apostrofy, pytania retoryczne czy eksklamacje. Pokazuje to, że są one również retorycznymi środkami mającymi na celu m.in. wzmocnić perswazyjność przekazu.

Kolejną grupą gestów narracyjnych wykorzystywaną przez Jana Pawła II podczas spotkania z młodzieżą w Gnieźnie były gesty ilustracyjne. W pewnym sensie naśladują one rzeczywistość, unaoczniają to, o czym mówi nadawca wypowiedzi. Są składnikami ruchowo-obrazowymi. Cechuje je duże podobieństwo do treści wyrażanych słowami, nie kopiują one jednak dokładnie tych słów (Załazińska 2012). W pewnym momencie spotkania z młodzieżą w Gnieźnie papież porównał je do wieczoru spędzonego przy ognisku. Zażartował, że długo ono potrwa, bo jest dopiero w początkowej fazie (,,a to dopiero etap przygotowawczy”). Słowom tym towarzyszy gest wykonany palcami, imitujący ruch rozniecania ognia. Jan Paweł II pokazuje, co się robi, aby ognisko zapłonęło. Taki gest ilustracyjny świadczy o nieformalnym charakterze wystąpienia, nie pełni funkcji perswazyjnej, ale ubogaca narrację, dookreśla ją o nowe treści, zmniejsza dystans między nadawcą i odbiorcą. Tego typu gest możemy również zaobserwować, kiedy papież mówi o tym, że następnego dnia będzie w Częstochowie. Ruchem ręki imituje wówczas lot, co pokazuje, jakim środkiem transportu się tam dostanie. W warstwie werbalnej nie ma o tym mowy, gest zatem dookreśla treści, przekazuje nowe informacje, a tym samym czyni wypowiedź bardziej atrakcyjną.

Inny jeszcze charakter mają gestualne metafory. Wyrażają one abstrakcyjne zjawiska, ukazując ich podobieństwa do właściwości fizycznych zobrazowanych gestem (Załazińska 2016). Klasycznym już przykładem gestu metaforycznego jest ruch dłoni naśladujący szale wagi pokazywany wtedy, gdy mowa nie o wadze, ale o abstrakcyjnych pojęciach, takich jak rozważanie jakiegoś problemu, zastanawianie się nad tym, co jest lepsze, co gorsze itp. Jan Paweł II wykonuje gest metaforyczny, opowiadając o tym, że młodzież poduczy go śpiewania. Pokazuje wtedy rękami czynność nakręcania czegoś, co przestało działać, np. zegarka. Można to rozumieć w ten sposób, że papież znał kiedyś te wszystkie pieśni doskonale, ale przez jakiś czas ich nie śpiewał, więc trzeba go „nakręcić”, przypomnieć, przywrócić do działania. Słowu poduczyć towarzyszy zatem gest „nakręcania”, który nie jest jego ilustracją, ale metaforą.

Przy analizie gestów Jana Pawła II podczas tego wystąpienia zwraca uwagę zmiana ich liczby i charakteru w drugiej części. Papież nie był już wówczas ograniczony kartkami, nie odtwarzał przygotowanego wcześniej tekstu, ale go tworzył, co na ogół sprzyja zwiększeniu zachowań gestycznych. Aneta Załazińska pisze: 
zaangażowanie emocjonalne mówiącego ma wpływ na naturalność gestykulacji i ilość pojawiających się gestów. Im człowiek bardziej jest zaangażowany w to, co mówi, im bardziej jest pobudzony emocjonalnie, tym więcej czyni gestów. Dlatego też sądzę, iż właśnie spontaniczne wypowiedzi mogą być najlepszym materiałem dla badań nad gestami, ich rolą w procesie komunikacji, dociekaniami ich wartości retorycznej oraz dla głębszych studiów poznawczych, poszukujących podstawowych gestaltów i prekonceptualnych schematów struktury myśli ludzkiej (2001: 114).

Jolanta Antas z kolei twierdzi, że:

im mocniej mówca angażuje się w treść własnej wypowiedzi, tym mniej wykonuje adaptacyjnych ruchów motorycznych dłoni i zaczyna używać rąk dla celów ilustrujących czy też obrazujących pojęcia abstrakcyjne, czy wreszcie wyznaczających akcenty logiczno-semantyczne i modalne (2001: 454-455).

\section{Podsumowanie}

Potoczno-okazjonalna sytuacja komunikacyjna daje bardzo duże możliwości stosowania werbalnych i niewerbalnych środków komunikowania. Przyjmuje się, że sytuacja potoczna uwolniona jest $\mathrm{z}$ dyscypliny protokołu dyplomatycznego czy zaleceń liturgicznych, wciąż jednak oczekuje się w niej, że mówca będzie przestrzegał pewnych ustalonych zasad, a więc np. przemawiał z zastosowaniem reguł sztuki retoryki. W momencie, kiedy sytuacja potoczna zaczyna nabierać cech sytuacji okazjonalnej, zmienia się temat, styl wypowiedzi, język, repertuar niewerbalnych środków wyrazu, zwłaszcza gestów. W potoczno-okazjonalnej sytuacji komunikacyjnej Jan Paweł II łączył ze sobą elementy przewidywalne i nieprzewidywalne, język retoryczny z językiem codziennym, gestykulację o charakterze perswazyjnym (głównie batuty) z taką, która wzbogacała tekst o nowe treści i pomagała nawiązać bezpośredni kontakt z odbiorcą (gesty metaforyczne i ilustracyjne). Pozwalał sobie również na żarty, przekomarzanie się, włączanie dodatkowych elementów, takich jak np. śpiew, dialog. Wykorzystując swoje predyspozycje dobrego mówcy, ale i aktora, umiejętnie posługującego się niewerbalnymi środkami wyrazu, nie tylko realizował funkcję perswazyjną swojego wystąpienia, zjednywał sobie sympatię tłumów, ale także budował wspólnotę ze swoimi odbiorcami i kreował własny, indywidualny styl komunikacji.

\section{Bibliografia}

Antas J., 2001, Co mówia ręce. Wprowadzenie do komunikacji niewerbalnej, w: Retoryka dziś. Teoria i praktyka, red. R. Przybylska i W. Przyczyna, Kraków, s. 437-460.

Głowiński M., Kostkiewiczowa T., Okopień-Sławińska A., Sławiński J., 1976, Słownik terminów literackich, Wrocław-Warszawa-Kraków-Gdańsk.

Grabias S., 2001, Język wachowaniach społecznych, Lublin.

Jan Paweł II, 2010, Pielgrzymki do ojczyzny. Przemówienia, homilie, Kraków. 
Jankosz M., 2018, Sytuacje komunikacyjne publicznych wystapień Jana Pawła II podczas I pielgrzymki do Polski, „Polonia Sacra”, nr 1(50), s. 183-194.

Korolko M., 1990, Sztuka retoryki. Przewodnik encyklopedyczny, Warszawa.

Kulik-Jęsik A., 2009, Etyka i retoryka w dziełach Jana Pawła II, w: Retoryka i etyka, red. B. Sobczak i H. Zgółkowa, Poznań, s. 135-147.

Laskowska E., 2010, Niektóre składniki sytuacji komunikacyjnej, w: Sytuacja komunikacyjna i jej parametry, red. G. Sawicka, Bydgoszcz, s. 70-76.

Miodek J., 1998, Osobliwości stylu Jana Pawła II, w: Twórczość Karola Wojtyty, red. Z.W. Solski, Wrocław, s. 22-26.

Poniewierski J., 2006, Gesty Jana Pawła II, Kraków.

Sawicka G., 2014, Wprowadzenie, w: Sytuacja komunikacyjna i jej parametry. „Być nadawca-być odbiorca”, red. G. Sawicka, W. Czechowski, Toruń, s. 5-10.

Załazińska A., 2001, Schematy myśli wyrażane w gestach, Kraków.

Załazińska A., 2012, Metoda analizy środków niewerbalnych pojawiajacych się podczas wypowiedzi (Na podstawie programu Kuba Wojewódzki), w: Instrukcja obstugi tekstów. Metody retoryki, red. J. Wasilewski, A. Nita, Sopot, s. 253-269.

Załazińska A., 2016, Obraz. Słowo. Gest, Kraków. 